\title{
Differentiation of donor primordial germ cells into functional gametes in the gonads of mixed-sex germline chimaeric chickens produced by transfer of primordial germ cells isolated from embryonic blood
}

\author{
M. Naito ${ }^{1}$, Y. Matsubara ${ }^{1}$, T. Harumi ${ }^{1}$, T. Tagami ${ }^{1}$, H. Kagami ${ }^{1 *}$, M. Sakurai ${ }^{2}$ and T. Kuwana ${ }^{3}$ \\ 'Genetic Engineering Laboratory, National Institute of Animal Industry, Tsukuba Norindanchi PO Box 5, Ibaraki 305-0901, Japan; \\ ${ }^{2}$ Laboratory of Immunobiology, National Institute of Animal Health, 3-1-1 Kannondai, Tsukuba, Ibaraki 305-0856, Japan; and ${ }^{3}$ Pathology \\ Section, National Institute for Minamata Disease, Minamata, Kumamoto 867-0008, Japan
}

\begin{abstract}
This study was carried out to elucidate whether primordial germ cells, obtained from embryonic blood and transferred into partially sterilized male and female recipient embryos, could differentiate into functional gametes and give rise to viable offspring. Manipulated embryos were cultured until hatching and the chicks were raised until maturity, when they were mated. When the sex of the donor primordial germ cells and the recipient embryo was the same, 15 out of 22 male chimaeric chickens $(68.2 \%)$ and 10 out of 16 female chimaeric chickens (62.5\%) produced donor-derived offspring. When the sex of the donor primordial germ cells and the recipient embryo was different, 4 out of 18 male chimaeric chickens ( $22.2 \%$ ) and 2 out of 18 female chimaeric chickens $(11.1 \%)$ produced donor-derived offspring. The rates of donor-derived offspring from the chimaeric chickens were $0.6-40.0 \%$ in male donor and male recipient and $0.4-34.9 \%$ in female donor and female recipient. However, the rates of donor-derived offspring from the chimaeric chickens were $0.4-0.9 \%$ in male donor and female recipient and $0.1-0.3 \%$ in female donor and male recipient. The presence of $\mathrm{W}$ chromosome-specific repeating sequences was detected in the sperm samples of male chimaeric chickens produced by transfer of female primordial germ cells. These results indicate that primordial germ cells isolated from embryonic blood can differentiate into functional gametes giving rise to viable offspring in the gonads of opposite-sex recipient embryos and chickens, although the efficiency was very low.
\end{abstract}

\section{Introduction}

Manipulation of primordial germ cells (PGCs) is a useful technique for studying the development and differentiation of germ cells in germline chimaeras because PGCs are progenitor cells of ova and spermatozoa. Avian PGCs originate from the epiblast (Eyal-Giladi et al., 1981) and are located on the ventral surface of the area pellucida at stage $X$ (Eyal-Giladi and Kochav, 1976) as monoclonal antibody SSEA-1/EMA-1-positive cells (Karagenc et al., 1996). They then translocate to the dorsal side of the hypoblast at stages $\mathrm{XI}-\mathrm{XIV}$ and are carried anteriorly to the germinal crescent region (Swift, 1914; Clawson and Domm, 1969). After that, they enter the blood vascular system and circulate temporarily throughout the embryo (Swift, 1914; Fujimoto et al., 1976). Finally, they migrate to the germinal ridges, future gonads, and differentiate into oogonia in female embryo and

*Present address: Department of Animal Science and Biotechnology, School of Veterinary Medicine, Azabu University, Sagamihara, Kanagawa 229-8501, Japan.

Revised manuscript received 20 May 1999. spermatogonia in male embryo (Nieuwkoop and Sutasurya, 1979; Kuwana, 1993).

In avian species, the male is the homogametic sex (ZZ), producing spermatozoa with the $Z$ chromosome, and the female is the heterogametic sex $(Z W)$, producing ova with either the $\mathrm{Z}$ or $\mathrm{W}$ chromosome. The development of embryo manipulation techniques has made it possible to produce mixed-sex chimaeric chickens by transfer of blastodermal cells or PGCs (Etches et al., 1997; Naito, 1997, 1998). If PGCs transferred into opposite-sex recipient embryos can differentiate into functional gametes, viable offspring derived from the donor PGCs can be produced efficiently via mixed-sex germline chimaeric chickens.

Same-sex and mixed-sex germline chimaeric chickens have been produced by transfer of stage $X$ blastodermal cells (Kagami et al., 1995, 1997). In these experiments, male or female donor blastodermal cells were transferred into same or opposite-sex recipient embryos and same-sex and mixedsex germline chimaeric chickens were produced. Both samesex and mixed-sex germline chimaeric chickens produced donor-derived offspring efficiently. Since stage $X$ 
blastodermal cells contain PGCs or their immediate precursor cells (Karagenc et al., 1996), it is clear that PGCs, or their immediate precursor cells at stage $X$, have the ability to differentiate into both male and female gametes, irrespective of their genetic sex, giving rise to viable offspring via germline chimaeric chickens.

Germline chimaeric chickens have also been produced by transfer of PGCs obtained from the blood of embryos at stages 13-15 (Hamburger and Hamilton, 1951; Tajima et al., 1993; Naito et al., 1994a,b, 1998a,b). Donor PGCs in these experiments were collected from the pooled blood of both male and female embryos, and a mixed population of male and female PGCs was transferred into male or female recipient embryos. If PGCs at stages 13-15 can differentiate into both functional male and female gametes, irrespective of their genetic sex, the male:female ratio of donor-derived offspring from germline chimaeric chickens should deviate from 1:1. No skewed male:female ratios of donor-derived offspring from the germline chimaeric chickens produced by transfer of a mixed population of male and female PGCs have been obtained to date (Naito et al., 1994a, 1998b). The results indicate that differentiation into functional gametes of PGCs transferred to the gonads of opposite-sex recipient embryos were restricted to some degree at some developmental stage (Naito et al., 1998b).

The efficiency of differentiation of PGCs into functional gametes in the gonads of opposite-sex recipient chick embryos seems to be limited when germline chimaeras are produced by transfer of mixed-sex stage 13-15 PGCs compared with transfer of stage $X$ blastodermal cells. Therefore, the present study was conducted to elucidate whether PGCs isolated from embryonic blood could differentiate into functional gametes and give rise to viable offspring when transferred into opposite-sex recipient embryos.

\section{Materials and Methods}

\section{Preparation of fertilized eggs and animal care}

The fertilized eggs of White Leghorn (WL) and Barred Plymouth Rock (BPR) chickens were obtained by artificial insemination from the genetic stocks maintained at the National Institute of Animal Industry. All animals received humane care as outlined in the Guide for the Care and Use of Experimental Animals (National Institute of Animal Industry Animal Care Committee).

\section{Preparation of donor primordial germ cells}

Fertilized BPR eggs were incubated at $38^{\circ} \mathrm{C}$ and $60 \%$ relative humidity in a forced air incubator (P-008; Showa Incubator Laboratory, Yono-shi, Saitama) for about $53 \mathrm{~h}$. Blood was collected using a fine glass micropipette (Naito et al., 1994a) from the dorsal aorta of embryos at stages 13-15, when most PGCs circulate in the bloodstream (Singh and Meyer, 1967; Nakamura et al., 1988). The blood collected from individual embryos was dispersed separately in KAv-1 medium; $\alpha$-MEM (number 11900-024; Gibco BRL, Grand Island, NY) supplemented with $1 \mathrm{mmol}$ D-glucose $\mathrm{l}^{-1}$, $5 \times 10^{-5} \mathrm{~mol} \quad 2$-mercaptoethanol $\mathrm{I}^{-1}, \quad 10 \mathrm{mmol} \quad \mathrm{N}-2-$ hydroxethylpiperazine- $N^{\prime}$-3-propanesulfonic acid (EPPS) $\mathrm{l}^{-1}$, $50 \mathrm{ml}$ fetal bovine serum $\mathrm{l}^{-1}, 50 \mathrm{ml}$ chicken serum $\mathrm{l}^{-1}, \mathrm{pH} 8.0$ (Kuwana et al., 1996). Primordial germ cells were then concentrated by Ficoll density gradient centrifugation (Yasuda et al., 1992). The PGC-rich fraction (PGCs constituted about $60 \%$ of the cells in this fraction) was dispersed separately in each sample in $50 \mu \mathrm{KAv}-1$ medium and placed in a plastic dish (Code 3001; Falcon, Becton Dickerson Co., Lincoln Park, NJ). After collecting the PGCs, the residual cells (mostly erythrocytes) were used for DNA extraction and sexing of donor embryos.

\section{Preparation of recipient embryos and primordial germ cell transfer}

Fertilized WL eggs were broken and the contents were put into glass vessels. Thick albumen was removed from the yolk by tilting the glass vessel, and the blastoderm was placed on top of the yolk by rotating the yolk. A needle $(27 \mathrm{G} \times 3 / 4$; Terumo, Tokyo) connected to the micropipette (P20; Gilson, Villiers-le-Bel) was inserted underneath the blastoderm layer and sucked a cell cluster containing about 700 cells from the central disc of the area pellucida (Kagami et al., 1997). The collected cells were used for DNA extraction and for sexing of recipient embryos. The manipulated embryos (yolks) were transferred into host eggshells, filled with thin albumen, sealed with cling film and plastic rings (Perry, 1988; Naito et al., 1990). The reconstituted eggs were incubated at $38^{\circ} \mathrm{C}$ and $60 \%$ relative humidity for about $53 \mathrm{~h}$. When the embryo reached stages 14-15, as observed through the aperture of the reconstituted egg, the plastic rings and cling film were taken off the reconstituted egg and the blood was drawn as much as possible $(4-10 \mu \mathrm{l})$ from the dorsal aorta of the exposed embryo by a fine glass micropipette. The eggs were resealed with cling film and plastic rings after adding a small amount of thin albumen to the embryo and they were incubated for 2-4h until injection of donor PGCs. Donor PGCs were picked up by a fine glass micropipette and dispersed in up to $1 \mu \mathrm{KAv}-1$ medium. The donor PGCs were injected into the bloodstream through the dorsal aorta of the recipient embryos. Half of the donor PGCs collected from one embryo were injected into a male recipient embryo and the other half were injected into a female recipient embryo. When the total number of PGCs collected from one embryo was small, all PGCs were transferred into one male or one female recipient embryo. The manipulated embryos were then transferred into large host eggshells and incubated until hatching (Rowlett and Simkiss, 1987; Perry, 1988; Naito et al., 1990).

\section{Sex identification of donor and recipient embryos}

DNA was extracted from the residual cells after the donor PGCs had been collected, and from the blastodermal cells collected from the recipient embryos, using a DNA 
extraction kit (SepaGene ${ }^{\mathrm{TM}}$; Sanko Junyaku, Tokyo) according to the manufacturer's instructions. The extracted DNA was dissolved in $50 \mu \mathrm{l}$ TE buffer $\left(10 \mathrm{mmol}\right.$ Tris- $\mathrm{HCl} \mathrm{l}^{-1}$,

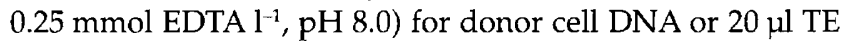
buffer for recipient cell DNA. PCR analysis for sexing was performed on the DNA samples, $1 \mu \mathrm{l}$ for donors and $5 \mu \mathrm{l}$ for recipients, according to the method of Clinton (1994).

The PCR was carried out using a programmable thermal controller (XE-4800; Nippon Techno Service, Ichikawa-shi, Chiba). The PCR reactions were performed in $50 \mu \mathrm{l} \mathrm{of} 10 \mathrm{mmol}$

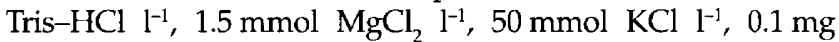
gelatin $\mathrm{ml}^{-1}, 200 \mu \mathrm{mol} \mathrm{dNTPs}^{-1}, 0.5 \mu \mathrm{mol}$ primers $\mathrm{l}^{-1}$ and $1 \mathrm{U}$ Taq polymerase (number R001B; Takara, Tokyo). The sequences of the primers for detecting the $W$ chromosome-specific repeating sequences (Kodama et al., 1987) were: $5^{\prime}$ CCCAAATATAACACGCTTCACT-3', 5'-GAAATGAATTATTTTCTGGCGAC-3' (Clinton, 1994). Control PCR reactions were carried out to ensure the presence of genomic DNA using primers: 5'-CAGATCAGTTTCTATCAGC-3', 5'TGTGACTTCAATGGTGACA-3', designed to amplify the chicken GAPDH gene (Clinton, 1994). After an initial denaturation step of $94^{\circ} \mathrm{C}$ for $2 \mathrm{~min}, 20$ cycles of amplification were performed; DNA was denatured at $94^{\circ} \mathrm{C}$ for $30 \mathrm{~s}$, annealed at $60^{\circ} \mathrm{C}$ for $30 \mathrm{~s}$ and extended at $72^{\circ} \mathrm{C}$ for $30 \mathrm{~s}$. The samples were then incubated at $72^{\circ} \mathrm{C}$ for $5 \mathrm{~min}$. For GAPDH gene PCR, the conditions were as described above except each cycle lasted $1 \mathrm{~min}$ and a total of 30 cycles was performed. After amplification, $5 \mu l$ of the product of each reaction was combined, separated on a $2 \%$ agarose gel, and the bands were visualized under UV light after ethidium bromide staining. A band of $315 \mathrm{bp}$ was detected in females, but not in males.

\section{Frequency of germline transmission of donor primordial germ cells}

WL chickens are homozygous dominant $(I / I)$ and BPR chickens are homozygous recessive $(i / i)$ for autosomal pigment inhibitor gene. Germline chimaerism of the putative chimaeric chickens produced by transfer of PGCs from BPR to WL chickens was tested by mating them with BPR chickens using artificial insemination, and the feather colour of their offspring was examined. Black offspring $(i / i)$ were derived from the donor PGC (BPR) and white offspring $(I / i)$ were derived from the recipient PGC (WL).

\section{Detection of W chromosome-specific repeating sequences in male ejaculates}

Sperm samples were collected from male chimaeric chickens. The collected sperm samples were washed with DPBS(-) (number 21300-025; Gibco BRL, Grand Island, NY) three times and DNA was extracted using the DNA extraction kit. Detection of $W$ chromosome-specific repeating sequences in the extracted DNA was carried out by PCR on $500 \mathrm{ng}$ DNA, and detection of GAPDH gene was carried out on 100 ng DNA as a control. The PCR conditions and analysis of PCR products were the same as for sexing of embryos.

\section{Results}

\section{Numbers of donor primordial germ cells collected from one embryo}

The numbers of PGCs obtained from the blood of individual embryos after Ficoll density gradient centrifugation varied among embryos, ranging from 20 to 806 per embryo, with a mean of $251.4 \pm 140.6$ (mean \pm SD; $n=187$ ). In male embryos, the number of PGCs obtained was $223.0 \pm 145.1$ (mean $\pm \mathrm{SD}, n=93$ ) and ranged from 20 to 661 per embryo. In female embryos, the number of PGCs obtained was $280.1 \pm 153.7$ (mean \pm SD; $n=94$ ) and ranged from 50 to 806 per embryo. The mean number of PGCs obtained from individual embryos was significantly $(P<0.05, F$ test) different between the male embryos and female embryos. The numbers of PGCs transferred into recipient embryos ranged from 15 to 431 .

\section{Sex identification of donor and recipient embryos, and survival and hatching rates of the recipient embryos}

The sex of donor and recipient embryos was clearly identified by PCR. DNA from the donor embryos was analysed twice and the same results were obtained in all embryos. In all recipient embryos, the sex identified by PCR was the same as the phenotypic sex of the hatched chickens.

The survival rate of the chick embryos after the removal of a cell cluster from the blastoderm was $59.8 \%$ (579 of 969) at day 3 of incubation. Twin embryos were sometimes observed (21.1\%; 122 of 579$)$ but all died within 7 days of incubation. Donor PGCs were transferred into the 314 recipient embryos sexed, and 83 chicks $(26.4 \%)$ hatched. Of these, 74 chickens matured and test mated.

\section{Frequency of donor-derived offspring from the chimaeric chickens}

When the sex of the donor embryo was the same as that of the recipient embryo, 15 out of the 22 male chickens $(68.2 \%)$ and ten out of the 16 female chimaeric chickens $(62.5 \%)$ produced donor-derived offspring. When the sex of the donor embryo differed from that of the recipient embryo, four out of the 18 male chimaeric chickens $(22.2 \%)$ and two out of the 18 female chimaeric chickens $(11.1 \%)$ produced donor-derived offspring. The percentages of chimaeric chickens that produced donor-derived offspring were significantly $(P<0.01$, chi-squared test) higher for same-sex combinations of donor and recipient embryos compared with different-sex combinations.

The results of the progeny test of chimaeric chickens are shown (Tables 1-4). When donor and recipient embryos were same-sex combinations, donor-derived offspring were efficiently obtained from the chimaeric chickens. The rates of donor-derived offspring from the chimaeric chickens were $0.6-40.0 \%$ in male donor and male recipient and $0.4-34.9 \%$ in female donor and female recipient. However, when donor and recipient embryos were of different sexes, few donorderived offspring were obtained from the chimaeric 
Table 1. Progeny test of chimaeric chickens produced by transfer of primordial germ cells from male Barred Plymouth Rock to male White Leghorn chickens

\begin{tabular}{|c|c|c|c|c|c|}
\hline $\begin{array}{l}\text { Chimaera } \\
\text { number }\end{array}$ & $\begin{array}{c}\text { Number of } \\
\text { primordial germ } \\
\text { cells transferred }\end{array}$ & $\begin{array}{c}\text { Number of } \\
\text { chicks hatched }\end{array}$ & $\begin{array}{c}\text { Number of } \\
\text { white chicks }\end{array}$ & $\begin{array}{c}\text { Number of } \\
\text { black chicks* }\end{array}$ & $\begin{array}{c}\text { Black chicks* } \\
(\%)\end{array}$ \\
\hline MM2 & 50 & 172 & 169 & 3 & 1.7 \\
\hline MM3 & 30 & 147 & 147 & 0 & 0 \\
\hline MM4 & 100 & 269 & 263 & 6 & 2.2 \\
\hline MM7 & 200 & 388 & 341 & 47 & 12.1 \\
\hline MM8 & 20 & 157 & 156 & 1 & 0.6 \\
\hline MM9 & 200 & 188 & 188 & 0 & 0 \\
\hline MM10 & 120 & 70 & 69 & 1 & 1.4 \\
\hline MM11 & 66 & 79 & 79 & 0 & 0 \\
\hline MM12 & 75 & 111 & 111 & 0 & 0 \\
\hline MM17 & 87 & 318 & 316 & 2 & 0.6 \\
\hline MM18 & 120 & 321 & 193 & 128 & 40.0 \\
\hline MM19 & 153 & 268 & 260 & 8 & 3.0 \\
\hline MM20 & 150 & 191 & 184 & 7 & 3.7 \\
\hline MM21 & 136 & 195 & 181 & 14 & 7.2 \\
\hline MM22 & 135 & 208 & 200 & 8 & 3.8 \\
\hline
\end{tabular}

*Donor-derived offspring.

Table 2. Progeny test of chimaeric chickens produced by transfer of primordial germ cells from female Barred Plymouth Rock to male White Leghorn chickens

\begin{tabular}{|c|c|c|c|c|c|c|}
\hline $\begin{array}{l}\text { Chimaera } \\
\text { number }\end{array}$ & $\begin{array}{c}\text { Number of } \\
\text { primordial germ } \\
\text { cells transferred }\end{array}$ & $\begin{array}{c}\text { Number of } \\
\text { chicks hatched }\end{array}$ & $\begin{array}{c}\text { Number of } \\
\text { white chicks }\end{array}$ & $\begin{array}{c}\text { Number of } \\
\text { black chicks* }\end{array}$ & $\begin{array}{c}\text { Black chicks } \\
(\%)\end{array}$ & $\begin{array}{l}\text { W-repeat } \\
\text { in semen }\end{array}$ \\
\hline FM2 & 80 & 130 & 130 & 0 & 0 & - \\
\hline FM3 & 200 & 175 & 175 & 0 & 0 & - \\
\hline FM4 & 90 & 208 & 208 & 0 & 0 & + \\
\hline FM7 & 258 & 673 & 672 & 1 & 0.1 & + \\
\hline FM8 & 75 & 209 & 209 & 0 & 0 & - \\
\hline FM9 & 100 & 459 & 459 & 0 & 0 & - \\
\hline FM10 & 112 & 496 & 496 & 0 & 0 & - \\
\hline FM11 & 143 & 571 & 571 & 0 & 0 & - \\
\hline FM12 & 100 & 434 & 434 & 0 & 0 & - \\
\hline FM17 & 218 & 321 & 320 & 1 & 0.3 & - \\
\hline FM18 & 300 & 80 & 80 & 0 & 0 & + \\
\hline
\end{tabular}

*Donor-derived offspring.

chickens. The rates of donor-derived offspring from the chimaeric chickens were $0.4-0.9 \%$ in male donor and female recipient and $0.1-0.3 \%$ in female donor and male recipient.

The efficiency of obtaining donor-derived offspring from the germline chimaeric chickens was enhanced by increasing the number of PGCs injected into recipient embryos (correlation coefficient: $r=0.20$, male donor and male recipient; $r=0.50$, female donor and female recipient), although these correlation coefficients are not statistically significant $(P>0.05)$. 
Table 3. Progeny test of chimaeric chickens produced by transfer of primordial germ cells from female Barred Plymouth Rock to female White Leghorn chickens

\begin{tabular}{|c|c|c|c|c|c|}
\hline $\begin{array}{l}\text { Chimaera } \\
\text { number }\end{array}$ & $\begin{array}{c}\text { Number of } \\
\text { primordial germ } \\
\text { cells transferred }\end{array}$ & $\begin{array}{c}\text { Number of } \\
\text { chicks hatched }\end{array}$ & $\begin{array}{l}\text { Number of } \\
\text { white chicks }\end{array}$ & $\begin{array}{c}\text { Number of } \\
\text { black chicks }\end{array}$ & $\begin{array}{c}\text { Black chicks } \\
(\%)\end{array}$ \\
\hline FF1 & 110 & 314 & 311 & 3 & 1.0 \\
\hline FF2 & 75 & 282 & 282 & 0 & 0 \\
\hline FF3 & 270 & 98 & 81 & 17 & 17.3 \\
\hline FF4 & 375 & 266 & 197 & 69 & 25.9 \\
\hline FF5 & 169 & 150 & 150 & 0 & 0 \\
\hline FF6 & 300 & 211 & 211 & 0 & 0 \\
\hline FF7 & 162 & 200 & 199 & 1 & 0.5 \\
\hline FF8 & 68 & 277 & 276 & 1 & 0.4 \\
\hline FF9 & 135 & 230 & 189 & 41 & 17.8 \\
\hline FF10 & 50 & 265 & 265 & 0 & 0 \\
\hline FF11 & 105 & 232 & 232 & 0 & 0 \\
\hline FF12 & 100 & 205 & 202 & 3 & 1.5 \\
\hline FF13 & 141 & 258 & 168 & 90 & 34.9 \\
\hline FF14 & 123 & 253 & 214 & 39 & 15.4 \\
\hline FF15 & 154 & 244 & 194 & 50 & 20.5 \\
\hline FF16 & 288 & 115 & 115 & 0 & 0 \\
\hline
\end{tabular}

${ }^{*}$ Donor-derived offspring.

Table 4. Progeny test of chimaeric chickens produced by transfer of primordial germ cells from male Barred Plymouth Rock to female White Leghorn chickens

\begin{tabular}{|c|c|c|c|c|c|}
\hline $\begin{array}{l}\text { Chimaera } \\
\text { number }\end{array}$ & $\begin{array}{c}\text { Number of } \\
\text { primordial germ } \\
\text { cells transferred }\end{array}$ & $\begin{array}{l}\text { Number of } \\
\text { chicks hatched }\end{array}$ & $\begin{array}{l}\text { Number of } \\
\text { white chicks }\end{array}$ & $\begin{array}{c}\text { Number of } \\
\text { black chicks }\end{array}$ & $\begin{array}{c}\text { Black chicks* } \\
(\%)\end{array}$ \\
\hline MF2 & 100 & 243 & 243 & 0 & 0 \\
\hline MF3 & 123 & 157 & 157 & 0 & 0 \\
\hline MF4 & 187 & 289 & 289 & 0 & 0 \\
\hline MF7 & 200 & 226 & 226 & 0 & 0 \\
\hline MF8 & 107 & 242 & 242 & 0 & 0 \\
\hline MF9 & 38 & 267 & 267 & 0 & 0 \\
\hline MF10 & 220 & 243 & 243 & 0 & 0 \\
\hline MF11 & 287 & 257 & 257 & 0 & 0 \\
\hline MF12 & 87 & 258 & 258 & 0 & 0 \\
\hline MF17 & 146 & 209 & 209 & 0 & 0 \\
\hline MF18 & 286 & 229 & 229 & 0 & 0 \\
\hline
\end{tabular}

*Donor-derived offspring.

Presence of $W$ chromosome-specific repeating sequences in the male ejaculates

Sperm samples obtained from the male chimaeric chickens produced by transfer of female PGCs were analysed for the presence of $\mathrm{W}$ chromosome-specific repeating sequences derived from female PGCs (Table 2). The W chromosome-specific DNA repeating sequences were detected by PCR in seven (FM4, FM5, FM7, FM14, FM15, FM16 and FM18) out of 18 male chimaeric chickens produced by transfer of female PGCs into male recipient embryos (Fig. 1). In three (FM5, FM7 and FM14) out of four male chimaeric chickens that produced donor-derived offspring, the $\mathrm{W}$ chromosome-specific repeating sequences were detected in their sperm samples, but in three (FM4, FM15 and FM16) male chimaeric chickens that produced no donor-derived offspring, the $\mathrm{W}$ chromosome-specific repeating sequences were also detected (Table 2). W chromosome-specific repeating sequences were not detected in the sperm samples of all the 22 male chimaeric chickens produced by transfer of male PGCs into male recipient embryos. 


\section{Discussion}

In this study, PGCs obtained from the blood of embryos incubated for 2 days were transferred into the same or opposite-sex recipient embryos. The differentiation of the PGCs introduced into the gonads of opposite-sex recipient embryos into functional gametes giving rise to viable offspring was partially impaired, and few donor-derived offspring were obtained from the mixed-sex chimaeric chickens, whereas the same-sex chimaeric chickens produced donor-derived offspring more efficiently. This finding explains the evidence that no apparent difference was observed in the male:female ratio of donor-derived offspring from the germline chimaeric chickens produced by transfer of a mixed population of male and female PGCs obtained from the embryonic blood (Naito et al., 1994a, 1998b).

However, PGCs or their immediate precursor cells at stage $X$ can differentiate into functional gametes efficiently in the gonads of opposite-sex chimaeric chickens when they are transferred into recipient embryos of the same developmental stage (Kagami et al., 1995, 1997). The discrepancy in the differentiation of PGCs in the gonads of opposite-sex embryos and chickens can be considered in view of the following two possibilities:

First, when chimaeric chickens were produced by transfer of stage X blastodermal cells, both PGCs and somatic cells were transferred into recipient embryos. A part of the blastodermal cells differentiated into Sertoli cells and Leydig cells in males, and granulosa cells and theca cells in females, which surround and nurse the germ cells. The sex of the Sertoli and Leydig cells or the granulosa and theca cells are the same as that of the PGCs transferred. As a result, the differentiation of PGCs into functional gametes in the gonads of chimaeric embryos and chickens proceeded normally. When chimaeric chickens were produced by transfer of PGCs obtained from the embryonic blood of embryos incubated for 2 days, donor PGCs were all surrounded by somatic cells of the opposite sex. As a result, normal gametogenesis of the PGCs in the gonads of chimaeric embryos and chickens was inhibited to some degree.

Second, the primary differentiation of PGCs as male or female cells took place by stages 13-15 during the migration to the germinal ridges, and normal gametogenesis of PGCs transferred into opposite-sex recipient embryos was partially impaired by this early stage sexual differentiation. That is, the ability of PGCs to differentiate into both male and female gametes, irrespective of their genetic sex, giving rise to viable offspring was lost rapidly during the first 2-3 days of incubation.

The frequency of obtaining donor-derived offspring from the germline chimaeric chickens was higher for the transfer of WL to BPR chickens than it was for the transfer of BPR to WL chickens (Naito et al., 1994a). In the present study, PGCs were transferred from BPR to WL chickens and the rates of donor-derived offspring from the same-sex germline chimaeric chickens were $0.4-40.0 \%$ in males and females. These frequencies were similar to that $(2.0-46.3 \%)$ reported by Naito et al. (1994a), but the efficiency of producing germline chimaeric chickens was low $(65.8 \%, 25 / 38)$ compared with previous results $(90.9 \%, 10 / 11$; Naito et al., 1994a). In the present study, PGCs collected from one embryo were transferred into one or two recipient embryos whereas, in our previous study, PGCs collected from the pooled blood of donor embryos were transferred into the recipient embryos (Naito et al., 1994a). Thus, combinations of donor cells and recipient embryos, especially immunological combinations, may affect the degree of acceptance of donor cells by recipient embryos. Further studies are required to clarify this issue.

Sex identification of recipient embryos can be carried out by $\mathrm{PCR}$ using DNA isolated from the stage $\mathrm{X}$ blastodermal cells obtained before incubation. Collection of a cell cluster from the blastoderm and subsequent incubation of the manipulated embryos were possible when an ex vivo culture method for chick embryos was available (Perry, 1988; Naito et al., 1990), but the viability of the manipulated embryos decreased to about $60 \%$ at day 3 of incubation and the hatching rate was about $10 \%$. Similar hatching rates were reported when blastodermal cells were removed from the stage $\mathrm{X}$ blastoderm by a fine glass capillary and the embryos were cultured ex vivo (Klein and Ellendorff, 1998). Moreover, twin embryos were sometimes observed after the manipulation of stage $X$ blastoderms using microinjection treatment of blastodermal cells (Naito et al., 1991), probably as a result of dividing the future embryonic axis when the needle was inserted underneath the blastoderm layer for sucking a cell cluster. The incidence of twin embryos further reduced the number of embryos available for PGC injection

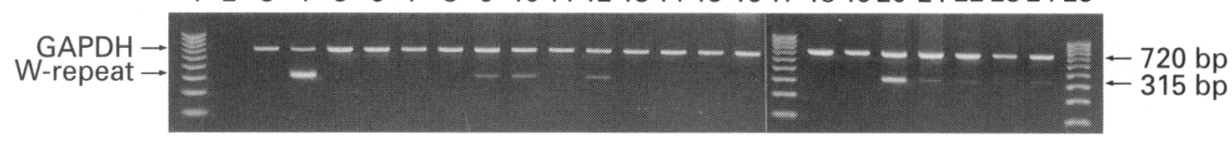

Fig. 1. Analysis of sperm samples of male chimaeric chickens produced by transfer of female primordial germ cells obtained from the embryonic blood. DNA was extracted from the sperm samples and analysed for the presence of the W chromosome-specific repeating sequences by PCR with W chromosome-specific primers. Endogenous GAPDH gene was detected as an internal control. Lanes 1, 17 and 25: molecular size marker; lane 2: negative control (water); lane 3: control (male blood DNA); lane 4: control (female blood DNA); lane 5: control (MM8, male germline chimaeric chicken produced by transfer of male primordial germ cells); lanes 6-16: FM1-FM11; lanes 18-24: FM12-FM18. The presence of the W chromosome-specific repeating sequences was detected in the sperm samples of FM4, FM5, FM7, FM14, FM15, FM16 and FM18. 
at stages $14-15$. Although the viability and hatching rates are decreased to some degree by sucking a cell cluster from the blastoderm, sex identification of recipient embryos is possible and effective for chick embryo manipulation, especially for investigating the sexual differentiation of chick embryos. Partially sterilized recipient embryos, produced by sucking a cell cluster at stage $X$ and removing blood at stages 14-15 and then injecting opposite-sex PGCs, grew normally, and the hatched chickens showed normal reproductive performance. In these chimaeric chickens, it seems that residual recipient-derived PGCs proliferated rapidly in the gonads of growing embryos.

In the present study, donor-derived offspring were obtained from the chimaeric chickens produced by the transfer of male PGCs into female recipient embryos, or the transfer of female PGCs into male recipient embryos, although the efficiency was very low. These results indicate that avian PGCs can differentiate into functional gametes in the gonads of opposite-sex embryos and chickens even when surrounded by opposite-sex somatic cells (Sertoli and Leydig cells or granulosa and theca cells). That is, male PGCs (ZZ) can differentiate into functional $Z$ chromosome-bearing ova in female chimaeric chickens, and female PGCs (ZW) can differentiate into functional $\mathrm{Z}$ chromosome-bearing spermatozoa in male chimaeric chickens. Moreover, female PGCs (ZW) may have entered the germline of male chimaeric chickens differentiated into $W$ chromosomebearing spermatozoa, since W chromosome-specific repeating sequences were detected in the sperm samples of male chimaeric chickens, although the frequency of $W$ chromosome-bearing spermatozoa is very low and their fertilizing ability is unknown. The presence of $\mathrm{W}$ chromosome-bearing spermatozoa has been reported in the analysis of the ejaculates of male chimaeric chickens produced by transfer of blastodermal cells or PGCs. The W chromosome-specific repeating sequences were detected by Southern hybridization (Kagami et al., 1995), PCR analysis (Simkiss et al., 1996) and in situ hybridization (Tagami et al., 1997). Thus, normal differentiation of PGCs into functional gametes does not necessarily require the presence of somatic cells of the same sex.

In avian species, aromatase is the key enzyme in the conversion of androgen to oestrogen and plays an important role in female sexual differentiation, whereas anti-Müllerian hormone and androgen play the key role in male sexual differentiation (Mizuno et al., 1993; Stevens, 1997; Shimada, 1998). The expression of the aromatase gene was first detected at days 5-7 of incubation in female chick embryos only (Mizuno et al., 1993) and sexually dimorphic expression of Sox9 (SRY related gene) was observed during the same period (Kent et al., 1996; Morais da Silva et al., 1996). These observations indicate that primary sexual differentiation of embryonic gonads occurs during 5-7 days of incubation in chickens. However, the results of the present study indicate that primary differentiation of PGCs occurs during the migratory phase, by day 3 of incubation, and that this primary differentiation of PGCs affects gametogenesis in the gonads of opposite-sex chimaeric chickens. In fact, more PGCs could be collected in female than in male embryos, probably reflecting the greater number of PGCs in female embryos and indicating that primary differentiation into PGCs had already taken place by day 3 of incubation, either actively or passively. A difference between the sexes in the timing of PGC proliferation in the gonads of chick embryos was reported by Zaccanti et al. (1990): PGC proliferation took place on days 4-5 in females and on days 6-7 in males. Clinton (1998) suggested that sexual differentiation in birds occurs at an earlier stage than has been thought. Sexreversed chickens have been produced by injecting aromatase inhibitor into eggs at day 5 of incubation (Elbrecht and Smith, 1992; Abinawanto et al., 1996, 1998). These sexreversed chickens were genetically female and phenotypically male and produced numerous spermatids and very few spermatozoa carrying $\mathrm{Z}$ or $\mathrm{W}$ chromosomes, indicating that the second meiosis occurred normally but that the transformation from spermatid to spermatozoon is partially impaired (Abinawanto et al., 1998). In these sexreversed chickens, the PGCs were present in female milieu up to day 5 of incubation and, thereafter, the PGCs were present in male milieu. However, PGCs or their immediate precursor cells at stage $X$ (day 0 ) transferred into oppositesex recipient embryos at the same developmental stage could differentiate normally into functional gametes giving rise to viable offspring via mixed-sex germline chimaeric chickens (Kagami et al., 1995, 1997).

In conclusion, it is considered that primary differentiation of PGCs took place by day 5 of incubation and that this process probably affects the transformation from spermatid to spermatozoon. Therefore, it is necessary to identify the genes involved in spermatogenesis, especially spermiogenesis, and to clarify the factors affecting the expression of these genes.

The authors are grateful to the staff of the Poultry Management Section of the National Institute of Animal Industry for taking care of the birds. This study was supported by the Global Environmental Research Fund from the Environmental Agency and the Special Coordination Fund for Promoting Science and Technology from the Science and Technology Agency of the Japanese Government.

\section{References}

Abinawanto, Shimada K, Yoshida K and Saito N (1996) Effects of aromatase inhibitor on sex differentiation and levels of $\mathrm{P}_{450_{17 \alpha}}$ and $\mathrm{P} 450_{\text {arrm }}$ messenger ribonucleic acid of gonads in chicken embryos General and Comparative Endocrinology $102241-246$

Abinawanto, Zhang C, Saito N, Matsuda Y and Shimada K (1998) Identification of sperm-bearing female-specific chromosome in the sexreversed chicken Jourtal of Experimental Zoology 280 65-72

Clawson RC and Domm LV (1969) Origin and early migration of primordial germ cells in the chick embryo: a study of the stages definitive primitive streak through eight somites American Jourmal of Anatomy 125 87-112

Clinton $\mathbf{M}$ (1994) A rapid protocol for sexing chick embryos (Gallus $g$. domesticus) Animal Genetics 25 361-362

Clinton M (1998) Sex determination and gonadal development: a bird's eye view Journal of Experimental Zoology 281 457-465

Elbrecht A and Smith RG (1992) Aromatase enzyme activity and sex determination in chickens Science 255 467-470

Etches RJ, Clark ME, Verrinder Gibbins AM and Cochran MB (1997) Production of chimeric chickens as intermidiates for gene transfer. In Transgenic Animals: Generation and Use pp 75-82 Ed. LM Houdebine. Harwood Academic Publishers, Amsterdam

Eyal-Giladi $\mathbf{H}$ and Kochav S (1976) From cleavage to primitive streak formation: a complementary normal table and a new look at the first stages 
of the development of the chick I. General morphology Developmental Biology 49 321-337

Eyal-Giladi H, Ginsburg M and Fabarof A (1981) Avian primordial germ cells are of epiblastic origin Journal of Embryology and Experimental Morphology 65 $139-147$

Fujimoto T, Ninomiya T and Ukeshima A (1976) Observations of the primordial germ cells in blood samples from the chick embryo Developmental Biology 49 278-282

Hamburger V and Hamilton HL (1951) A series of normal stages in the development of the chick embryo Journal of Morphology 849-92

Kagami H, Clark ME, Verrinder Gibbins AM and Etches RJ (1995) Sexual differentiation of chimeric chickens containing $\mathrm{ZZ}$ and $\mathrm{ZW}$ cells in the germline Molecular Reproduction and Development 42 379-387

Kagami H, Tagami T, Matsubara Y, Harumi T, Hanada H, Maruyama K, Sakurai M, Kuwana T and Naito M (1997) The developmental origin of primordial germ cells and the transmission of the donor-derived gametes in mixed-sex germline chimeras to the offspring in the chicken Molecular Reproduction and Development 48 501-510

Karagenc L, Cinnamon Y, Ginsburg M and Petitte JN (1996) Origin of primordial germ cells in the prestreak chick embryo Developmental Genetics 19 290-301

Kent J, Wheatley SC, Andrews JE, Sinclair AH and Koopman P (1996) A male-specific role for $S O X 9$ in vertebrate sex determination Development 122 2813-2822

Klein S and Ellendorff $\mathbf{F}$ (1998) Analysis of chicken embryonic development after removal of blastodermal cells for sexing British Poultry Science 39 482-487

Kodama H, Saitoh H, Tone M, Kuhara S, Sakaki Y and Mizuno S (1987) Nucleotide sequences and unusual electrophoretic behavior of the $W$ chromosome-specific repeating DNA units of the domestic fowl, Gallus gallus domesticus. Chromosoma 96 18-25

Kuwana T (1993) Migration of avian primordial germ cells toward the gonadal anlage Development Growth and Differentiation 35 237-243

Kuwana T, Hashimoto K, Nakanishi A, Yasuda Y, Tajima $A$ and Naito $\mathbf{M}$ (1996) Long-term culture of avian embryonic cells in vitro. International Journal of Developmental Biology 40 1061-1064

Mizuno S, Saitoh Y, Nomura O, Kunita R, Ohtomo K, Nishimori K, Ono H and Saitoh H (1993) Sex-specific DNA sequence in Galliformes and their application to the study of sex differentiation. In Manipulation of the Avian Genome pp 257-274 Ed. RJ Etches and AM Verrinder Gibbins. CRC Press, Boca Raton, FL

Morais da Silva S, Hacker A, Harley V, Goodfellow P, Swain A and LovellBadge R (1996) Sox9 expression during gonadal development implies a conserved role for the gene in testis differentiation in mammals and birds Nature Genetics $1462-68$

Naito M (1997) The microinjection of DNA into early chicken embryo. In Transgenic Animals: Generation and Use pp 69-73 Ed. LM Houdebine. Harwood Academic Publishers, Amsterdam

Naito M (1998) Manipulation of primordial germ cells for avian transgenesis AgBiotech News and Information $10397-404$

Naito M, Nirasawa K and Oishi T (1990) Development in culture of the chick embryo from fertilized ovum to hatching Journal of Experimental Zoology 254 322-326

Naito M, Watanabe M, Nirasawa K and Oishi T (1991) Developmental ability of twin embryos produced by microinjection treatment into chick blastoderm Poultry Science 70 1261-1264

Naito M, Tajima A, Yasuda Y and Kuwana T (1994a) Production of germline chimeric chickens, with high transmission rate of donor-derived gametes, produced by transfer of primordial germ cells Molecular Reproduction and Development 39 153-161

Naito M, Tajima A, Tagami T, Yasuda Y and Kuwana T (1994b) Preservation of chick primordial germ cells in liquid nitrogen and subsequent production of viable offspring Journal of Reproduction and Fertility 102 321-325

Naito M, Sakurai M and Kuwana T (1998a) Expression of exogenous DNA in the gonads of chimaeric chicken embryos produced by transfer of primordial germ cells transfected in vitro and subsequent fate of the introduced DNA Journal of Reproduction and Fertility 113 137-143

Naito M, Tajima A, Yasuda Y and Kuwana T (1998b) Donor primordial germ cell-derived offspring from recipient germline chimaeric chickens: absence of long term immune rejection and effects on sex ratios British Poultry Science 39 20-23

Nakamura M, Kuwana T, Miyayama Y and Fujimoto T (1988) Extragonadal distribution of primordial germ cells in the early chick embryo Anatomical Record 22290-94

Nieuwkoop PD and Sutasurya LA (1979) Primordial Germ Cells in the Chordates Cambridge University Press, Cambridge

Perry MM (1988) A complete culture system for the chick embryo Nature 331 $70-72$

Rowlett K and Simkiss K (1987) Explanted embryo culture: in vitro and in ovo techniques for domestic fowl British Poultry Science 28 91-101

Shimada K (1998) Gene expression of steroidogenic enzymes in chicken embryonic gonads Joumal of Experimental Zoology $281450-456$

Simkiss K, Luke G and Behnam J (1996) Female chromosomes in cockerel ejaculates Proceedings of the Royal Society of London B 263 1245-1249

Singh RP and Meyer DB (1967) Primordial germ cells in blood smears from chick embryos Science 156 1503-1504

Stevens L (1997) Sex chromosomes and sex determining mechanisms in birds Science Progress 80 197-216

Swift CH (1914) Origin and early history of the primordial germ cells in the chick American Journal of Anatomy 15 483-516

Tagami T, Matsubara Y, Hanada H and Naito M (1997) Differentiation of female chicken primordial germ cells into spermatozoa in male gonads Development Growth and Differentiation $39267-271$

Tajima A, Naito M, Yasuda Y and Kuwana T (1993) Production of germ line chimera by transfer of primordial germ cells in domestic chicken (Gallus domesticus) Theriogenology 40 509-519

Yasuda Y, Tajima A, Fujimoto T and Kuwana T (1992) A method to obtain avian germ-line chimaeras using isolated primordial germ cells Journal of Reproduction and Fertility 96 521-528

Zaccanti F, Vallisneri M and Quaglia A (1990) Early aspects of sex differentiation in the gonads of chick embryos Differentiation 43 71-80 